\title{
Utjecaj aspiracije traheje na nastanak nozokomijalnih pneumonija
}

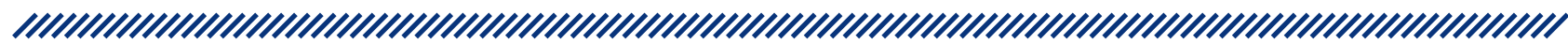

1 Mirjana Saratlija

1 Odjel za pedijatrijsku intenzivnu medicinu, Klinika za pedijatriju KBC-a Zagreb

\section{Sažetak}

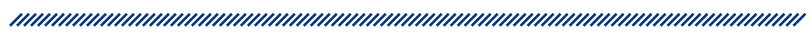

Nozokomijalna pneumonija vodeća je komplikacija liječenja djece u jedinicama intenzivne medicine, sa znatnim utjecajem na njihov mortalitet i morbiditet. Nastaje u približno 8 do $28 \%$ strojno ventiliranih bolesnika, a učestalost joj se povećava za najmanje 1 do $3 \%$ po svakom danu trajanja strojne ventilacije. 0 prohodnosti dišnog puta ovisi kvaliteta disanja i izmjena plinova. Jedini je način održavanja prohodnosti dišnog puta pravodobna i učinkovita aspiracija traheje. Aspiracijom uklanjamo sekret iz dišnog puta, pospješujemo respiratornu funkciju i sprječavamo sekundarnu infekciju pluća. Aspiracija se može provoditi otvorenim i zatvorenim sustavom. Otvorenim, klasičnim sustavom aspiraciju provode dvije medicinske sestre. Zatvorenim sustavom aspirira jedna medicinska sestra, pacijent se ne odvaja od respiratora i pri tome je smanjena mogućnost unosa patogena iz vanjske okoline. Sam postupak aspiracije zatvorenim sustavom ima nekoliko koraka kojih se treba pridržavati kako bi aspiracija bila uspješna. Potrebno je odrediti pravu veličinu zatvorenog sustava u odnosu na veličinu tubusa, pravilno izmjeriti distancu i pridržavati se zadanih mjera i postupaka prilikom aspiracije.
Ključne riječi: nozokomijalna pneumonija, strojna ventilacija, aspiracija traheje

Datum primitka: 15.06.2018.

Datum prihvaćanja: 07.10.2018.

DOI: $10.24141 / 1 / 5 / 1 / 7$

Adresa za dopisivanje: Mirjana Saratlija, bacc. med. techn.

Klinika za pedijatriju, KBC Zagreb Kišpatićeva 12, 10000 Zagreb

e-pošta: msaratlija@net.hr 


\section{Uvod}

Kisik je nužan za život svake stanice, a nedovoljna prisutnost kisika u tkivima i u krvi dovodi do hipoksije i hipoksemije. Opskrba tkiva kisikom ovisi o arterijskom tlaku kisika, količini hemoglobina u krvi i udarnom volumenu srca. ${ }^{1}$ Kvaliteta disanja i izmjena plinova ovisi o prohodnosti dišnog puta. Razna stanja kritično bolesnog djeteta onemogućuju izmjenu plinova i zahtijevaju strojnu ventilaciju. Koncept umjetne respiracije poznat je još od 16. stoljeća, a tek je u 20. stoljeću strojna ventilacija ušla u terapijsku uporabu. ${ }^{2}$

Aktivnosti pri kojima medicinska sestra pomaže usmjerene su na zadovoljavanje ljudskih potreba prema osnovnim načelima zdravstvene njege. ${ }^{3}$ Pacijentu na strojnoj ventilaciji potrebno je osigurati prohodnost dišnog puta. Jedini je način održavanja prohodnosti dišnog puta pravodobna i učinkovita aspiracija traheje. To je postupak kojim s pomoću negativnog tlaka, aspiratora i aspiracijskog katetera odgovarajuće veličine uklanjamo sekret iz dišnih putova, osiguravamo prohodnost, pospješujemo respiratornu funkciju i sprječavamo sekundarnu infekciju pluća.

Nozokomijalna pneumonija vodeća je komplikacija djece $u$ jedinicama intenzivne medicine, sa znatnim utjecajem na njihov mortalitet i morbiditet. Nastaje u približno 8 do $28 \%$ strojno ventiliranih bolesnika, a učestalost joj se povećava za najmanje 1 do $3 \%$ po svakom danu trajanja strojne ventilacije. ${ }^{4}$

Aspiracija je bolan i izrazito neugodan postupak, popraćen osjećajem gušenja. Tehnika aspiracije zahtijeva i poznavanje posljedica neprimjerenog zahvata. Neki bolesnici ne toleriraju aspiraciju te ih je potrebno sedirati. ${ }^{5}$ lako ne postoji jedinstveni standard aspiracijskog protokola, nijedna tehnika nije znanstveno utemeljena, razlikuje se od institucije do institucije, ipak su neka opća načela zajednička. ${ }^{6}$ Aspiracija se može provoditi otvorenim i zatvorenim sustavom. Tijekom oba postupka ventilacija je ometana, tako da moguće epizode hipoksije i posljedične bradikardije te promjene intrakranijskog tlaka treba svesti na minimum. Dugi niz godina provodila se samo aspiracija otvorenim sustavom. Postupak izvode dvije medicinske sestre, pacijent se odvaja od respiratora. Uz sterilne katetere odgovarajuće veličine, priprema se sterilna fiziološka otopina, štrcaljke, samošireći balon prilagođen dobi djeteta te jednokratne sterilne PVC rukavice. Poželjna je uporaba zaštitnih maski i naočala. Sestra koja asistira odvaja pacijenta od respiratora, ukapa sterilnu 0,9-postotnu fiziološku otopinu u tubus, lagano ventilira pacijenta samoširećim balonom, drugom rukom oslobodi aspiracijski kateter koji drži druga sestra, vodeći računa o sterilnosti postupka te pridržava tubus dok se kateterom počinje aspirirati. Sestra koja aspirira jednom rukom drži cijev aspiratora, gdje pri ulasku u tubus „preknika” cijev da ne ulazi pod tlakom. Tako sprječava oštećenje sluznice. Dominantnom rukom ulazi sterilnim kateterom u tubus i nježno ga rotirajući među prstima provodi postupak aspiracije. Sam postupak aspiracije traje od pet do deset sekundi i ponavlja se ovisno o količini i konzistenciji dobivenog sekreta. ${ }^{7}$ Između aspiracija druga sestra manualno ventilira pacijenta dva do tri puta, prateći vitalne funkcije. Kateter mora biti manji od 1/2 promjera tubusa ili kanile, jer veći kateter oštećuje stijenku traheje i lakše dolazi do hipoksije. Negativni tlak aspiratora mora biti dovoljno jak da aspirira sekret, ali ne i prejak, jer to može dovesti do krvarenja iz traheje i oštećenja, a nepravilnim postupcima aspiracije možemo izazvati trajna oštećenja traheje i bronha te druge komplikacije kao što je pneumotoraks i plućno krvarenje. Od velike je važnosti brzina i spretnost izvođenja postupka zbog moguće hipoksije kojoj izlažemo pacijenta.

Zatvorenim sustavom aspiriramo bez odvajanja od respiratora, što sprječava desaturaciju i pruža veću zaštitu od infekcije dišnih putova, a ujedno štiti medicinsko osoblje od aerosola pacijenta. Aspiraciju traheje zatvorenim sustavom provodi jedna medicinska sestra. Sam postupak aspiracije ne zahtijeva sterilne rukavice, jer imamo zatvoreni sustav, gdje je kateter za aspiraciju obavijen zaštitnim sterilnim PVC omotačem. Proksimalni dio katetera spaja se na tubus. Na kateteru postoji zaštitni ventil koji onemogućava nenamjernu aspiraciju i dva adaptera koja omogućavaju primjenu fiziološke otopine za vrijeme aspiracije te ispiranje katetera po završetku aspiracije. Ispiranjem katetera sprječava se rasap bakterija iz katetera u tubus, odnosno sekundarna infekcija.

Na samom aspiracijskom kateteru imamo u pozadini naznačenu duljinu u centimetrima. Kateteri su dostupni u različitim veličinama, od broja 5 nadalje. Uspješnost dobre i kvalitetne aspiracije zatvorenim sustavom ovisi o pravilnom odabiru veličine i pravilno izmjerenoj distanci katetera. Veličina katetera mora odgovarati veličini tubusa, $i$ to tako da se veličina tubusa množi s dva i tako dobijemo veličinu katetera u FR, što pretvoreno u brojke znači da kateter mora biti dvaput većeg broja od broja tubusa. 
Postupak mjerenja ima nekoliko koraka. Duljini tubusa dodajemo duljinu postavljenog konektora i ukupan zbroj odgovara broju katetera koju očitavamo u prozorčiću. ${ }^{8}$ Primjer mjerenja: ako nam je točka mjerenja na broju 18, dodajemo 5 centimetara (duljina konektora), što znači da kateter treba uvesti u tubus do oznake 23. Ovim postupkom mjerenja sigurni smo da smo odredili dobru distancu, jer zatvorenom aspiracijom nemamo čujni odgovor, što kod većine izaziva nepovjerenje i strah da aspiracija nije zadovoljavajuća. Sama se aspiracija izvodi tako da kateterom ulazimo do označenog broja i bez rotiranja katetera brzo izlazimo. Jednom izmjerena distanca primjenjuje se sve dok nije došlo do promjene veličine tubusa uslijed reintubacije i slično.

Novi način aspiracije nametnuo je i potrebu za kontinuiranim praćenjem provođenja postupka, kako bismo uvidjeli njegove prednosti i nedostatke.

\section{Cilj rada}

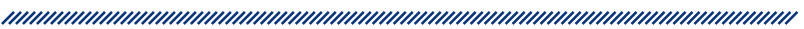

1. Usporediti učestalost pneumonija udruženih sa strojnom ventilacijom $u$ djece ventilirane dulje od 48 sati, ovisno o načinu aspiracije (otvorena ili zatvorena).

2. Utvrditi učestalost komplikacija zatvorenog načina aspiracije i potrebu prelaska na otvorenu aspiraciju.

\section{Metode rada}

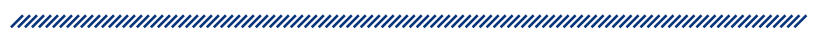

Istraživanje je provedeno na uzorku od 56 djece koja su bila na strojnoj ventilaciji dulje od četrdeset osam sati. Kod njih se provodio zatvoreni oblik aspiracije traheje.

U svrhu istraživanja upotrijebljeni su podaci iz medicinske dokumentacije djece na strojnoj ventilaciji kroz godinu i pol dana i retrospektivno medicinska dokumentacija djece u periodu od 18 mjeseci ranije, kada se primjenjivala samo otvorena metoda aspiracije traheje.

Kod djece je praćena: dob, prosječna duljina liječenja na strojnoj ventilaciji, liječnička dijagnoza (skupina), ishod liječenja, trajanje strojne ventilacije, broj aspiracija po pacijentu, komplikacije zatvorene aspiracije i potreba prelaska na otvorenu metodu, izgled sadržaja aspirata, mikrobiološki nalazi aspirata traheje ( $>48$ sati nakon intubacije).

\section{Rasprava}

U periodu od osamnaest mjeseci na odjelu dječje intenzivne njege hospitalizirano je 473 bolesnika. Od ukupnog broja bolesnika 56 ih je provelo dulje od 48 sati na strojnoj ventilaciji. Kod svih je njih primjenjivana zatvorena metoda aspiracije traheje. Ukupno su aspirirani 6960 puta, što prosječno po bolesniku iznosi 124 aspiracije. Prosječna je duljina liječenja na strojnoj ventilaciji četrnaest dana. Djeca su bila u dobi od 2 dana do 16 godina. Od toga je petero novorođenčadi $(9 \%)$ i 28 djece dojenačke dobi (50\%). U dobi od jedne do tri godine bilo je $12(21 \%)$, od tri do pet godina dvoje (4\%), od pet do sedam godina bilo je troje djece (5\%), od sedam do 12 godina bilo je četvero djece $(7 \%)$ te od 12 do 16 godina dvoje djece (4\%). Podijeljeni po medicinskim dijagnozama - skupinama, liječeni su neurokirurški, kardiokirurški, kirurški, bili su hematološki bolesnici te su skupinu ostalih činili bolesnici koji su primljeni zbog respiratorne insuficijencije kao hitnog stanja, a zahtijevali su strojnu ventilaciju. Neurokirurških pacijenata bilo je osam (14\%), kardiokirurških 26 (47\%), hematoloških šest (11\%), kirurških sedam (12\%) te ostalih devet (16\%). Kod troje neurokirurške djece (37 \%) izolirani su mikroorganizmi iz kulture aspirata, dok je kod ostalih petero (63 \%) aspirat bio sterilan.Uspješnost je aspiracije $100 \%$. Kod desetero kardiokirurške djece bila je pozitivna kultura aspirata traheje (38\%), a kod ostalih 16 bolesnika (62\%) kultura aspirata bila je sterilna. Ovdje je uspješnost aspiracije $96 \%$. Kod $50 \%$ hematoloških bolesnika kultura aspirata bila je pozitivna, a kod ostalih 50 \% sterilna. Uspješnost je zatvorene aspiracije $100 \%$. Kod pet kirurških bolesnika bila je sterilna kultura aspirata traheje (72\%), a kod dvoje djece ( $28 \%$ ) pozitivna. Uspješnost je aspiracije je $100 \%$. Bakteriološki status aspirata traheje bolesnika na strojnoj ventilaciji različitih medicinskih dijagnoza kod četiri bolesnika (44\%) pozitivna je kultura aspirata, a kod ostalih pet (56\%) nalaz je sterilan. U ovoj je skupini kod sedam pacijenata (78 \%) uspješna zatvorena aspiracija, dok je 
kod dvoje (22\%) s komplikacijama, gdje se prešlo na otvorenu metodu aspiracije.

Pozitivni mikrobiološki rezultati aspirata traheje približno su podjednako zastupljeni u svim kategorijama bolesnika osim hematoloških, gdje je u $50 \%$ pozitivna kultura aspirata traheje. To je razumljivo, s obzirom na njihov smanjeni imunitet zbog osnovne bolesti, kao i zbog specifičnog, citostatskog liječenja. Iz dobivenih rezultata može se zaključiti da zatvoreni oblik aspiracije odgovara svim dobnim skupinama. Isto tako, medicinska dijagnoza nije uvjetovala uspješnost ili komplikaciju primjene zatvorene metode aspiracije. Rijetko se moralo prijeći na otvoreni oblik aspiracije. Troje djece (5\%) nije toleriralo zatvorenu aspiraciju i kod njih smo prešli na otvorenu aspiraciju. Riječ je bila o specifičnim slučajevima, od kojih je jedno dijete, u dobi od dvije godine, nakon kardiokirurškog zahvata razvilo emfizem pluća s obiljem pjenušavog sekreta. Tu se morao primijeniti i tzv. pasivni ekspirij kako bih se oslobodio zarobljeni zrak i tada je otvoreni oblik aspiracije bio nužan i učinkovit. Sličan je problem imao još jedan bolesnik s infekcijom RSV-om, u dobi od sedam mjeseci. Kod njega je bio prisutan ljepljivi sadržaj aspirata traheje i zatvorenom aspiracijom nije se uspjelo kvalitetno aspirirati te se prešlo na otvoreni način aspiracije, gdje se ventiliranjem samoširećim balonom uspjelo lakše eliminirati ljepljivi sadržaj i kvalitetno aspirirati. Treći je bolesnik imao 16 godina. Imao je obilje gustog sekreta koji je začepljivao sondu te smo i tu prešli na otvoreni oblik aspiracije, prvenstveno radi uštede seta za zatvorenu aspiraciju. Kod otvorene aspiracije svaki se put upotrebljava novi, sterilni kateter, mijenja se i po potrebi za vrijeme aspiracije. Kod ovog smo pacijenta imali problem dugotrajne ventilacije, gdje je bilo potrebno učiniti traheotomiju. Isto tako, ovaj je bolesnik pravi primjer da se kod veće djece i odraslih pristupa traheotomiji nakon 72 sata kod očekivane dugotrajne strojne ventilacije. ${ }^{9}$ $\mathrm{Na}$ vrijeme učinjena traheotomija smanjuje pojavnost nozokomijalnih pneumonija. ${ }^{10}$ Kod ovog pacijenta to je i učinjeno, nakon čega nije bilo problema prilikom aspiracije traheje, a ujedno je sama toaleta bila učinkovitija.

Uspoređujući učestalost infekcije s respiratorom povezanih pneumonija, dobiveni rezultati pokazuju da nema razlike između primjene otvorenog i zatvorenog sustava za aspiraciju traheje. Oba su postupka povezana s rizikom razvoja nozokomijalnih s ventilatorom povezanih infekcija. ${ }^{11}$ Načelno bi postupak zatvorenog sustava za aspiraciju trebao smanjiti njihovu učestalost, s obzirom na to da se ne otvara sustav cijevi respiratora, ali s druge strane, nazočan je rizik rasta bakterija u samom susta- vu. Postupak intubacije i strojne ventilacije agresivna je metoda koja narušava prirodne obrambene mehanizme domaćina. Vlažan i ugrijan zrak preko sustava cijevi na respiratoru omogućuje lakše odstranjenje sekreta, a samim je time i vlažna podloga za razvoj mikroorganizama u cijelom sustavu.

Rezultati 16 randomiziranih, kontroliranih kliničkih studija koje su uspoređivale otvoreni i zatvoreni sustav aspiracije $u$, doduše, odraslih bolesnika strojno ventiliranih dulje od 24 sata nisu dokazali razlike ni u učestalosti infekcija - $s$ ventilatorom povezanih pneumonija ni u mortalitetu, što je u skladu i s našim rezultatima. ${ }^{12,13} \mathrm{Mi}$ šljenja su da je opravdana i isplativa primjena zatvorenog sustava za aspiraciju kod bolesnika koji su dulje od četiri dana na strojnoj ventilaciji, iako je otvorena jeftinija. Isto tako, smatraju da ne bi trebalo mijenjati sustav za aspiraciju svaka 24 sata, kao ni cijevi respiratora, osim us slučaju vidljive kontaminacije. Njihovi rezultati govore da nije bilo razlike u nastajanju nozokomijalnih pneumonija kod onih gdje su sustav za aspiraciju mijenjali svaka 24 sata i onih gdje nisu mijenjali ni sustav za aspiraciju ni cijevi respiratora. Kod svih naših pacijenata zatvoreni smo sustav mijenjali svaka 24 sata. Cijevi respiratora mijenjane su svakih četrnaest dana.

Istraživanje u kojem je praćena vrijednost intrakranijskog tlaka kod pacijenata s neurološkim oštećenjem dokazalo je znatnu razliku u porastu intrakranijskog tlaka kod otvorene metode aspiracije u odnosu na zatvorenu. ${ }^{14}$

Primjenjujući zatvoreni sustav za aspiraciju znatno je manje epizoda hipoksije i bradikardije. Zatvorena je metoda uzrokovala manje promjena hemodinamičkog stanja dojenčadi. ${ }^{15}$ Mjerenjem postotka zasićenosti kisikom u arterijskoj krvi odmah i tri minute nakon aspiracije dobivena je znatna razlika u smanjenju vrijednosti kod primjene otvorene aspiracije u usporedbi sa zatvorenom metodom.

Općenito, pretražujući literaturu dalo bih se zaključiti da je kod neonatalnih i pedijatrijskih pacijenata relativno malo kliničkih istraživanja koja se bave ovom temom.

Znajući da smo prosječno svakog bolesnika aspirirali 124 puta i da postupak aspiracije traje oko šest minuta, vidljiva je znatna ušteda vremena u usporedbi s aspiracijom koju izvode dvije medicinske sestre, što je slučaj pri aspiraciji otvorenim sustavom. Razmišljajući o rizicima hipoksije i bradikardije te porasta intrakranijskog tlaka koji se pri aspiraciji javlja, a uzimajući u obzir jednostavnost postupka i manju potrošnju vremena, mišljenja smo da je zatvoreni sustav bolji od otvorenog sustava za aspiraciju. Primjena zatvorenog sustava 
opravdana je kod pacijenata koji su na strojnoj ventilaciji dulje od 24 sata, dok je kod kratkotrajne ventilacije poželjno primjenjivati otvoreni sustav za aspiraciju.

\section{Zaključak}

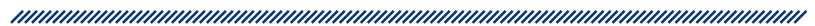

Dobiveni rezultati aspiracije traheje zatvorenim sustavom i njihov utjecaj na nastanak nozokomijalnih pneumonija ne razlikuju se u odnosu na aspiraciju otvorenim sustavom. U prvoj je skupini 56 bolesnika. Kod 34 bolesnika (61\%) aspirat traheje bio je sterilan. Kod 22 bolesnika (39\%) nalaz kulture aspirata bio je pozitivan. Kod sedam bolesnika (32\%) izolirani su gram-pozitivni mikroorganizmi (MSSA, MRSA). Kod 12 bolesnika (54\%) izolirani su gram-negativni mikroorganizmi (Pseudomonas aeruginosa, Escherichia coli i Klebsiella pneumoniae).

Kod tri bolesnika (14 \%) izolirana je Candida albicans. Ekstubiran je 41 bolesnik (72\%), traheotomirano je pet bolesnika (9\%), a umrlo je 12 bolesnika (19\%).

U kontrolnoj je skupini 62 bolesnika. Kod njih se aspiracija traheje provodila otvorenim sustavom. Kod 38 bolesnika (62\%) nalaz kulture aspirata traheje bio je sterilan. Kod 24 bolesnika (38\%) izolirani su mikroorganizmi. Kod šest bolesnika ( $25 \%$ ) izolirani su gram-pozitivni mikroorganizmi (MSSA, MRSA). Kod 13 bolesnika (54\%) izolirani su gram-negativni mikroorganizmi (Pseudomonas aeruginosa, Escherichia colli, Enterobacter spp. Klebsiella pneumoniae). Kod pet bolesnika (21\%) izolirana je Candida albicans. Ekstubirano je 47 bolesnika (75\%), četiri su bolesnika (7\%) traheotomirana, a 11 je bolesnika umrlo (18\%).

Kontinuiranom primjenom zatvorenog sustava za aspiraciju traheje stekli smo novu vještinu za kvalitetno provođenje postupka. Dokazali smo prednost zatvorene aspiracije i prihvatili njezinu jednostavnost. $U$ svrhu daljnjeg istraživanja u tijeku je prikupljanje podataka mikrobioloških rezultata aspirata traheje kod pacijenata čiji sustav za zatvorenu aspiraciju mijenjamo svaka 72 sata. Tako ćemo moći usporediti dobivene rezultate s rezultatima kad smo sustav mijenjali svaka 24 sata.

\section{Literatura}

1. Disanje. Medicinska fiziologija. Ur. Guyton i Hall. Medicinska naklada - Zagreb, 2003; 432-491.

2. Avery GB, MA, McDonald GM, Neonatology, Lippincott Williams, 5. izd. 2000: 237-321.

3. Henderson V, Osnovna načela zdravstvene njege, HUSE, 1994.

4. Combes P, Fauvage B, Oleyer C. Nosocomial pneumonia in mechanically ventilated patients, a prospective randomised evaluation of the Stericath closed suctioning system, Intensive Care Med. 2000; 26(7): 878-882.

5. Napredno održavanje života djece i novorođenčadi, $\mathrm{Hr}$ vatsko društvo za reanimatologiju, HLZ-a, Zagreb, 2007: 23-31.

6. Lorente L, Lecuona M, Jimenez A, Mora ML, Sierra A, Tracheal suction by closed system without daily change versus open system, Intensive Care Medicine. 2006; 32 (4): 538-544.

7. Kostantinov T, Špičko J. Aspiracija novorođenčeta. Peti tečaj trajnog usavršavanja hrvatskih neonatalnih sestara, Neonatologija, Zagreb, 2003: 24-31.

8. Carlon GC, Fox SJ, Ackerman NJ. Evaluation of a Closed-tracheal Suction System. Crit Care Med. 1987; 15(5): 522-525.

9. Lewis T, Oliver G. Improving tracheostomy care for ward patients. Nursing Standard. 2005; 19(19): 33-37.

10. Rumbak MJ. The Pathogenesis of Ventilator-Associated Pneumonia. Resp Crit Care Med 2002; 23 (5): 275-278.

11. Muscedere J, Rewa O.,McKechnie K, Jiang X, Laporta D, Heyland DK. Subglottic secretion drainage for the prevention of ventilator-associated pneumonia: a systematic review and meta-analysis. Crit Care Med. kolovoz 2011; 39(8): 1985-1991.

12. Subirana M, Sola I, Benito S. Closed Tracheal Suction Systems Versus Open Tracheal Suction Systems for Mechanically Ventilated Adult Patients. Cochrane Database of Systematic Reviews 2007, Issue 4. Art. No.: CD004581. DOI: 10.1002/14651858.CD004581.pub2.

13. Cordero L, Sananes M, Ayers LW. Comparison of a Closed (Trach Care MAC) With an Open Endotracheal Suction System in Small Premature Infants. J Perinatol. 2000; 20(3): 151-156.

14. Uğraş GA, Aksoy G. The effects of open and closed endotracheal suctioning on intracranial pressure and cerebral perfusion pressure: a crossover, single-blind clinical trial. J Neurosci Nurs. prosinac 2012; 44(6): E1-8.: 10.1097/JNN.0b013e3182682f69. Pub Med.

15. Taheri P1, Asgari N, Mohammadizadeh M, Golchin M.The effect of open and closed endotracheal tube suctioning system on respiratory parameters of infants undergoing mechanical ventilation. Iran J Nurs Midwifery Res. siječanj 2012; 17(1): 26-29. 


\section{THE INFLUENCE OF TRACHEA ASPIRATION ON NOSOCOMIAL PNEUMONIA DEVELOPMENT}

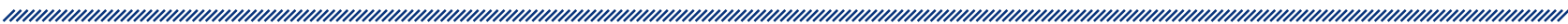

1 Mirjana Saratlija

1 Department of pediatric intensive care, Pediatrics Clinic KBC - Zagreb

\section{Abstract}

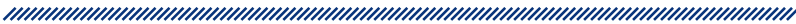

Nosocomial pneumonia is the leading complication in the treatment of children in intensive care units, with significant impact on their mortality and morbidity. It occurs in approximately 8-28\% of mechanicallyventilated patients, and the incidence is increased by at least $1-3 \%$ per each day of mechanical ventilation. Breath quality and gas exchange depend on the airway passage. The only way to maintain airway passage is timely and effective trachea aspiration. With aspiration, we remove secretion from the airway, increase respiratory function and prevent secondary pneumonia. Aspiration can be carried out by an open and closed system. An open, classic aspiration system is carried out by two nurses. Closed system aspiration is performed by one nurse, the patient is not taken off the respirator and thereby the possibility of the pathogen entering from the outside environment is reduced. Aspiration process with the closed system has several steps that need to be followed for aspiration to be successful. It is necessary to determine the right size of the closed system relative to the size of the tube, to properly measure the distance and to adhere to the set measures and procedures during aspiration.
Keywords: nosocomial pneumonia, mechanical ventilation, trachea aspiration 